\title{
TESTIMONIO
}

\section{EL LENGUAJE EN LA CONQUISTA MILITAR Y ESPIRITUAL DE MÉXICO}

Eduardo Matos Moctezuma

$\mathrm{F}^{1 \text { lenguaje, la palabra, es el medio por excelencia que nos }}$ Lermite expresarnos y a la vez entendernos con los otros. Ya sea de manera oral o escrita, en pictografías o en obras plenas de simbolismo, su papel resulta de potencial ayuda en las relaciones que se establecen entre los humanos. De los factores que ayudaron a la conquista militar de Tenochtitlan y Tlatelolco estuvo el del uso de varias lenguas indígenas, como el náhuatl, el totonaca, el maya y el español. En mi estudio sobre las posibles causales que provocaron la caída de esas ciudades -psicológicas, económicas, militares y de salud-, ubico el lenguaje dentro de las causas militares en razón de que en diversas ocasiones sirvió como nexo importante entre vencedores y vencidos y, más aún, como medio de conocer con antelación los movimientos que los mexicas o aztecas planeaban en contra de sus enemigos. Por otra parte, una vez consumada la conquista militar tendrá lugar otra conquista que siempre he considerada más ardua aún: la espiritual. Los primeros frailes misioneros acudieron a conocer la lengua de los recién conquistados para llevar su palabra evangelizadora y al mismo tiempo saber acerca de muchos de los aspectos de la vida de los indígenas con el fin, como dice 
fray Bernardino de Sahagún, de no ser engañados por ellos. Así, se trataba de utilizar tan formidable medio con fines de conquista espiritual además de recurrir a danzas, catecismos y otros entre los que no faltaron acciones coercitivas en contra de los indígenas. ${ }^{1}$

\section{EL LENGUAJE EN LA CONQUISTA MILITAR}

Dentro del marco de la guerra de conquista tenemos muchos ejemplos de cómo se utilizó el lenguaje en pro de la causa peninsular. El antecedente de esto lo tenemos en el momento en que Hernán Cortés envía una carta a los náufragos que se encontraban en tierras mayas para que se incorporan a sus huestes. La carta dice en su parte sustancial:

Señores y hermanos, aquí, en Cozumel, he sabido que estáis en poder de un cacique detenidos, y os pido por merced que luego os vengáis aquí, a Cozumel, que para ello envío un navío con soldados, si lo hobiésedes menester, y rescate para dar a esos indios con quien estáis; y lleva el navío de plazo ocho días para os aguardar $[\ldots]^{2}$

Lo que sigue ya lo sabemos: Jerónimo de Aguilar se incorpora a la empresa conquistadora en tanto que Gonzalo Guerrero permanece entre los mayas. Los dos hablaban el maya después de alrededor de siete años de permanecer entre ellos a raíz del naufragio que sufrieron. El primero viste como maya y el sol ha quemado su cuerpo, por lo que al llegar frente a sus coterráneos no lo reconocen hasta que dice " $¡$ Dios y Santa María e Sevilla!” en un español, como dice Bernal, "mal mascado y peor pronunciado".

1 Matos, "La Conquista de México".

2 Díaz del Castillo, Historia verdadera de la conquista de la Nueva España, pp. 98-99. 
La flota continúa su viaje y llega a costas de Tabasco, en donde Cortés utiliza a Jerónimo para entenderse con los lugareños. Allí se lleva a cabo la batalla de Centla, que provoca muertes en ambos bandos llevando la peor parte el grupo maya. Después de la batalla le son entregadas a Cortés 20 mujeres, una de las cuales era Malintzin, quien hablaba varias lenguas indígenas, como el náhuatl, el maya yucateco y el maya chontal. De ahí en adelante la situación va a cambiar. El capitán extremeño cuenta con un aliado formidable: la manera de comunicarse con la gente local en donde tanto Jerónimo como la Malinche juegan un papel decisivo. Así lo percibe Bernal Díaz cuando relata:

[...] doña Marina sabía le lengua de Guazacualco, que es la propia de México [náhuatl], y sabía la de Tabasco, como Jerónimo de Aguilar sabía la de Yucatán y Tabasco, que es toda una [maya yucateco y maya chontal]. Entendíanse bien, y el Aguilar lo declaraba en castilla a Cortés; fue un gran principio para nuestra conquista. Y ansí nos hacían todas las cosas, loado sea Dios, muy prósperamente. He querido declarar esto porque sin doña Marina no podíamos entender la lengua de la Nueva España y México. ${ }^{3}$

Al llegar a costas veracruzanas funda la Villa Rica de la Vera Cruz al sentirse seguro y en terrenos que no le son hostiles, como había ocurrido al paso por tierras mayas. La queja de los totonacas no se hace esperar: están sujetos como tributarios al señor Moctezuma de allende los volcanes. Cortés, hábilmente, aprovecha esa situación y los redime del yugo mexica. Manda a encallar las naves y así evita lo que algunos de sus hombres deseaban, regresar a Cuba tras la desobediencia de Cortés hacia Diego Velázquez, gobernador de la isla. Instalados en el lugar, la importancia de los dos personajes -Malintzin y Jerónimo-va

3 Díaz del Castillo, Historia verdadera de la conquista de la Nueva España, pp. 135-136. 
a continuar con su labor de intérpretes o "lenguas". Una de ellas fue cuando Moctezuma, inquieto, envía magos y agoreros además de regalos con el fin de alejar a los españoles. Vano intento. Los obsequios de oro y plata avivan más el interés de los recién llegados por marchar hacia Tenochtitlan. El cacique de Cempoala les da bastimentos, guerreros y guías. Comienza, pues, la marcha hacia la capital del imperio mexica.

A continuación relataré algunos de los pasajes importantes de la empresa conquistadora en que vemos la utilización que se hace de lo antes dicho. Cuando arriban a San Juan de Ulúa menciona Bernal Díaz cómo llegaron dos canoas muy grandes con indios mexicanos y se dirigieron a la nave principal en que estaba Cortés. Preguntaron en náhuatl quién era el Tetuán (tlatoani). Dice Bernal: "Y Marina, que bien lo entendió, porque sabía muy bien la lengua [...]”, les mostró a Cortés. Los mexicas le hicieron acatamientos y le dijeron al capitán español que quiénes eran y qué buscaban, además de ofrecer apoyo si algo habían menester. Continúa Bernal Díaz comentando: "Y Cortés respondió con las dos lenguas, Aguilar y doña Marina, que se lo tenía en merced [...]". ${ }^{4}$

Este primer encuentro con gentes mexicas es interesante, pues conforme a lo que relata el cronista los mexicas desean saber cuál es la intención de los recién llegados, a lo que Cortés respondió que era para verlos y comerciar, lo que los tranquilizó. Algunas embajadas se llevan a cabo entre Moctezuma y el capitán español en donde vemos la participación de los traductores.

Pero vayamos a algunos ejemplos que tuvieron lugar en el avance hacia la ciudad tenochca. Uno de los primeros a mencionar es el encuentro con las gentes de Tlaxcala. Es importante advertir que los tlaxcaltecas estaban en guerra constante con Tenochtitlan y, aunque era un territorio independiente formado

\footnotetext{
4 Díaz del Castillo, Historia verdadera de la conquista de la Nueva España, p. 136.
} 
por cuatro señoríos, sentían el amago de las fuerzas mexicas. Recordemos que las "guerras floridas" entre ambos grupos se hacían con el fin de capturar enemigos de un bando u otro para ser enviados al sacrificio. Siempre he pensado que esta práctica fue la razón por la que los mexicas no conquistaron a los belicosos tlaxcaltecas.

Recibidos al principio los españoles en plan agresivo, los tlaxcaltecas pronto se convencen de apoyar a los españoles. Lo que en un principio fue rechazo, en especial de parte de Xicoténcatl el Joven, poco después se convertirá en una ayuda particularmente importante para el grupo conquistador. Después de dialogar los consejeros tlaxcaltecas con su gobernante, Xicoténcatl el Viejo, van a decidir a favor de ayudar a los extranjeros. En este momento, que será decisivo, entran en juego los traductores de Cortés, quienes le van informando de los avances de las pláticas. Es importante hacer ver cómo fueron varias las embajadas que Moctezuma envía con regalos de oro y plata y otros productos, todas encaminadas a alejar a los peninsulares. Una de ellas ocurre cuando vencen a los tlaxcaltecas, lo que dio mucho gusto al tlatoani mexica, quien manda decir por medio de sus enviados "que viésemos cuánto quería de tributo cada año para nuestro gran Emperador, que lo dará en oro y plata y ropa y piedras de chalchiuis, con tal que no fuésemos a México". ${ }^{5}$

Llegados a la ciudad de Tlaxcala Cortés pregunta a Xicoténcatl el Viejo y a Maseescaci -otro gran señor tlaxcalteca- acerca de las características de la ciudad de Tenochtitlan. La información que recibe es sumamente valiosa: se le dice que las calzadas tienen puentes de madera de trecho en trecho y que, alzando un puente, se aíslan las otras partes. También informan que las casas tienen azoteas y en ellas hay mamparas "y pueden pelear desde encima dellas". Se le informa un dato que será determinante: el

5 Díaz del Castillo, Historia verdadera de la conquista de la Nueva España, p. 250. 
modo como se abastece la ciudad: "Y la manera como se provee la cibdad de agua dulce desde una fuente que se dice Chapultepeque, que está de la cibdad obra de media legua; va el agua por unos edificios y llega en parte que con canoas la llevan a vender por las calles". 6

A lo anterior hay que agregar los datos que aportan los tlaxcaltecas acerca del armamento que tenían los mexicas. Así lo señala el cronista-soldado:

Y luego contaron de la manera de las armas, que eran varas de a dos gajos que tiraban con tiraderas (átlatl) que pasan cualesquier armas; y muchos buenos flecheros y otros con lanzas de pedernales, que tienen una braza de cuchilla, hechas de arte que cortan más que navajas, y rodelas y armas de algodón; e muchos honderos con piedras rollizas, e otras lanzas muy largas e grandes, e espadas de a dos manos de navajas (macáhuitl) [...]. Y como nuestro capitán y todos nosotros estábamos ya informados de antes de todo lo que decían aquellos caciques[...] ?

Con tan señalada e importante información de tipo militar los españoles conocían de antemano las características de la ciudad de Tenochtitlan aun sin haber llegado a ella, así como el armamento enemigo. ¡Cuántos ejércitos hoy día quisieran disponer de tan privilegiada información de sus adversarios!

Veamos ahora lo que acontece cuando Cortés decide marchar con destino a Cholula en su camino a Tenochtitlan. Los tlaxcaltecas le aconsejan que no vaya por allí, sino que tome el camino por Huejotzingo que son sus parientes y amigos. El capitán español opta por ir por Cholula ya que le dicen que es gran población y está cerca de otras ciudades de las que se puede

${ }^{6}$ Díaz del Castillo, Historia verdadera de la conquista de la Nueva España, p. 267.

7 Díaz del Castillo, Historia verdadera de la conquista de la Nueva Espa$\tilde{n} a$, p. 267. 
abastecer. Finalmente llegan a Cholula. Esta ciudad estaba bajo el control de Moctezuma y fueron varias las embajadas enviadas por el tlatoani tenochca que apercibieron a Cortés de no seguir adelante. Bernal Díaz señala que fueron bien recibidos y alimentados, pero al tercer día cesó el apoyo y se decía que había en las afueras de la ciudad escuadrones de hasta 20000 hombres prestos a entrar a Cholula y atacar a los españoles e indígenas cempoaltecas y tlaxcaltecas que los acompañaban. Cortés pide a los embajadores de Moctezuma que soliciten a los caciques que les den alimentos: "E desque aquello vio nuestro capitán, dijo a doña Marina é Aguilar, nuestras lenguas, que dijesen a los embajadores del gran Montezuma que allí estaban, que mandasen a los caciques traer de comer". ${ }^{8}$ Ese mismo día llegan nuevos enviados del tlatoani quienes le hacen la siguiente petición: "e dijeron a Cortés muy desvergonzadamente que su señor les enviaba a decir que no fuésemos a su cibdad, porque no tenía qué nos dar de comer[...]". ${ }^{9}$

Todo lo anterior era entendido de una y otra parte gracias a los dos traductores. Pero llegamos al punto en que la Malinche atrae a personas de alto rango de Cholula para que digan ciertas cosas a Cortés. Así lo relata Bernal: “[...] y dijo a doña Marina que llevase más chalchiuis a los dos papas [sacerdotes], y que los trajese consigo [...] Y la doña Marina fue y les habló de tal manera, que lo sabía muy bien hacer, y con dádivas vinieron luego con ella". Cortés les hace ver que deben decir la verdad y ellos le comentan: "E dijeron que la verdad es que su señor Montezuma supo que íbamos aquella cibdad [...] que allí en Cholula nos matasen o llevasen atados a México, e que había enviado el

\footnotetext{
${ }^{8}$ Díaz del Castillo, Historia verdadera de la conquista de la Nueva España, I, pp. 281-282.

9 Díaz del Castillo, Historia verdadera de la conquista de la Nueva España, I, p. 282.
} 
día antes veinte mil hombres de guerra, y que la mitad están ya aquí dentro desta cibdad e la otra mitad están cerca de aquí". ${ }^{10}$

A continuación viene la versión muy conocida de cómo una anciana secretamente llegó con doña Marina acompañada de un hijo suyo para decirle que se preparaba un ataque en contra de los españoles. El texto es largo, pero vale la pena verlo pues muestra la astucia de la Malinche para obtener información de primera mano:

Como la vio moza y de buen parecer y rica, le dijo y aconsejó que se fuese con ella a su casa, si quería escapar la vida, porque ciertamente aquella noche u otro día nos habían de matar a todos, porque ya estaba así mandado y concertado por el gran Montezuma, para que entre los de aquella cibdad y los mexicanos se juntasen y no quedase ninguno de nosotros a vida, e nos llevasen atados a México. Y que, porque sabe esto y por mancilla que tenía de la doña Marina, se lo venía a decir, y que tomase todo su hato y se fuese con ella a su casa y que allí la casaría con su hijo, hermano de otro mozo que traía la vieja, que la acompañaba. E como la entendió la doña Marina, y en todo era muy avisada, le dijo: “ $; O$ Oh. Madre, que mucho tengo que agradeceros eso que me decís! Yo me fuera agora con vos, sino que no tengo aquí de quien me fiar para llevar mis mantas y joyas de oro, que es mucho. Por vuestra vida madre, que aguardéis un poco vos y vuestro hijo, y esta noche nos iremos, que agora ya veis que estos teules están velando y sentirnos han". Y la vieja creyó lo que le decía y quedose con ella platicando. Y le preguntó que de qué manera nos habían de matar e cómo e cuándo e adónde se hizo el concierto. Y la vieja se lo dijo ni más ni menos que lo habían dicho los dos papas. Y respondió la doña Marina "Pues ¿cómo siendo tan secreto ese negocio, lo alcanzaste vos a saber?”. Dijo que su marido se lo había dicho, que es capitán de una parcialidad de

${ }^{10}$ Díaz del Castillo, Historia verdadera de la conquista de la Nueva España, I, p. 284. 
aquella cibdad y, como tal capitán, está agora con la gente de guerra que tiene a cargo, dando orden para que se junten en las barrancas con los escuadrones del gran Montezuma, y que cree que estarán juntos esperando para cuando fuésemos, y que allí nos matarían. Y que esto del concierto que lo sabe tres días había, porque de México enviaron a su marido un atambor dorado e a otros tres capitanes también les envío ricas mantas y joyas de oro, porque nos llevasen atados a su señor Montezuma. Y la doña Marina, como lo oyó, disimuló con la vieja y dijo: “¡Oh, cuánto me huelgo en saber que vuestro hijo con quien me queréis casar es persona principal! Mucho hemos estado hablando; no querría que nos sintiesen. Por eso, madre, aguardad aquí; comenzaré a traer mi hacienda, porque no lo podré sacar todo junto, e vos y vuestro hijo, mi hermano, lo guardaréis y luego nos podremos ir”. Y la vieja todo se lo creía. Y sentose de reposo la vieja y su hijo. Y la doña Marina entra de presto donde estaba el capitán y le dice todo lo que pasó con la india, la cual luego la mandó traer ante él y la tornó a preguntar sobre las traiciones y conciertos[... $]^{11}$

Del diálogo se desprenden varias cosas: por un lado, la manera inteligente en que Malinche logra ganarse la confianza de la mujer y la forma de inducirla a que le diga acerca de los planes de Moctezuma en los que involucra a los de Cholula. A esto se une el dato del número de guerreros prestos para el ataque. Esto nos da una idea de quién era Malinche y del odio que se tenía contra los mexicas por su actitud conquistadora y de sometimiento de otras poblaciones indígenas. El final de todo esto lo sabemos. Cortés se adelanta y ataca y la mortandad de enemigos es enorme.

El relato anterior del paso por Cholula resalta los triunfos guerreros de los españoles y sus aliados. Insiste Bernal Díaz en

11 Díaz del Castillo, Historia verdadera de la conquista de la Nueva Espa$\tilde{n} a, \mathrm{I}, \mathrm{pp} .286-287$. 
destacar que, para ese momento, los triunfos de Centla y contra los mismos tlaxcaltecas antes de que fueran sus aliados, además de lo acontecido en Cholula, tenían con gran preocupación a Moctezuma, quien invocaba a sus dioses para saber cómo actuar. Pone de manifiesto el cronista que, al parecer, querían dejarlos entrar a Tenochtitlan para luego acabar con ellos. Pese a esto relata cómo Moctezuma manda escuadrones guerreros a apostarse en uno de los dos caminos posibles para avanzar hacia su ciudad. Uno de los caminos está limpio y desbrozado en tanto que el otro tiene ramajes que dificultan el paso. Era una invitación para que tomaran el primero, en donde estaban colocadas las huestes de Moctezuma. Estas estrategias militares por parte de los mexicas no dieron resultado y es interesante constatar, una vez más, cómo la actitud del tlatoani siempre fue la de tratar de alejar a los españoles. Cuando no lo logró por medio de regalos de oro, plata, mantas, etc., acude a las armas como medio de detener al enemigo. Los espías del tlatoani jugaban un papel importante pues por medio de ellos se enteraba de los pasos que daban los recién llegados. Al no lograr su objetivo, Moctezuma ve, no exento de tristeza y abatido, que las tropas enemigas prácticamente están a las puertas de Tenochtitlan. Al cruzar la sierra los españoles, el tlatoani va a intentar su cometido de persuadirlos de que regresen y usa la misma táctica de enviar regalos, pero todo es inútil. Moctezuma acude a Cacamatzin, señor de Texcoco, para que vaya personalmente ante Cortés. Así lo hace y el boato y acompañamiento que trae Cacama sorprende a los hispanos. Dice Bernal Díaz: "porque venía en andas muy ricas, labradas de plumas verdes y mucha argentería y otras ricas pedrerías engastadas en arboledas de oro que en ellas traía de oro muy fino. Y traían las andas a cuestas ocho principales, y todos según decían, eran señores de pueblos". ${ }^{12}$ El mensaje de que es

12 Díaz del Castillo, Historia verdadera de la conquista de la Nueva España, I, p. 306. 
portador indica una especie de bienvenida ante lo imposible: detener a los llegados de allende el mar.

Lo que sigue lo sabemos. Las tropas españolas entran a Iztapalapa, ciudad gobernada por el hermano de Moctezuma, Cuitláhuac. El encuentro entre Moctezuma y Cortés se da en la calzada de Ixtapalapa y luego son alojados en el palacio de Axayácatl, ubicado hacia el ángulo suroeste fuera de la gran plaza principal de Tenochtitlan. Después de una serie de vicisitudes, Cortés hace prisionero a Moctezuma y otros señores y los tiene sujetos dentro del palacio que les sirve de morada. Pronto Cortés tiene que partir a la costa pues ha sido avisado que ha llegado una flota para detenerlo al mando de Pánfilo de Narváez. Deja el mando en manos de Pedro de Alvarado, quien va a ser protagonista de aquella matanza de indígenas que celebraban la fiesta de Tóxcatl. Esto sublima los ánimos mexicas, quienes atacan a los españoles y logran encerrarlos en su palacio. Violentos ataques se dejan sentir y Cortés es avisado de los apremios que padecen los sitiados. Después de vencer a Narváez regresa a grandes jornadas a Tenochtitlan. El asedio es de tal magnitud que Cortés pide a Moctezuma que se asome por la azotea para aplacar a las tropas mexicas. El mismo capitán dice en su segunda carta de relación lo siguiente:

Y el dicho Muteczuma [...] dijo que le sacasen a las azoteas de la fortaleza, y que él hablaría a los capitanes de aquella gente y les harían que cesase la guerra. E yo lo hice sacar, y en llegando a un pretil que salía fuera de la fortaleza, queriendo hablar a la gente que por allí combatía, le dieron una pedrada los suyos en la cabeza, tan grande, que de allí a tres días murió; e yo le hice saber así muerto a dos indios de los que estaban presos, e a cuestas lo llevaron a la gente, y no sé de lo que dél se hicieron $[. . .]^{13}$

13 Cortés, s. f., p. 233. 
Las palabras anteriores las contradice Bernal Díaz, pues en una parte de su relato señala cómo el mismo Moctezuma le había dicho a Cortés estas palabras: "Yo tengo creído que no aprovecharé cosa ninguna para que cese la guerra, porque ya tienen alzado otro señor y se han propuesto no dejaros salir de aquí con vida; y así creo que todos vosotros habéis de morir”. El nuevo señor de los mexicas era Cuitláhuac. Bernal coincide con Cortés en cuanto a lo de las pedradas, pero aquí viene la incógnita de la muerte del tlatoani: la versión española es la que acabamos de consignar mientras que la versión indígena indica lo contrario: que fueron los españoles quienes lo mataron. Voy a transcribir lo que leemos en la Relación del origen de los indios que babitan esta Nueva España según sus historias: "[...] y yendo a buscar al gran Rey Motecuczuma dizen que le hallaron muerto á puñaladas, que le mataron los españoles á él y á los demás principales que tenían consigo la noche que se huyeron, y este fue el desastrado y afrentoso fin de aquel desdichado Rey [...]". ${ }^{14}$

Don Fernando Alvarado Tezozómoc escribe en su Crónica mexicáyotl al respecto: “En el año 2-pedernal, '1520 años', fue cuando murió el señor Moteuczoma Xocoyotl, rey de Tenochtitlan, hijo de Axayacatzin; reinó diez y nueve años; a los tres los mataron los 'españoles"”. 15

Otro documento importante lo constituyen las Relaciones de Chalco-Amaquemecan de don Domingo de San Antón Muñón Chimalpahin, quien escribió: "En el mes de Tecuilhuitontli, los españoles dieron muerte al Moteuhczomatzin haciéndolo estrangular, y después de eso huyeron aprovechando las sombras de la noche”.16

Existen documentos como el llamado Códice Moctezuma y otros más en los que se insiste en la muerte de Moctezuma

14 Códice Ramírez, p. 91.

15 Alvarado Tezozómoc, Crónica mexicáyotl, p. 149.

16 Chimalpahin, Relaciones originales de Chalco Amaquemecan, p. 236. 
por parte de los conquistadores. Me inclino por las versiones indígenas (pese a que fueron escritas mucho después de los acontecimientos) ya que los mismos españoles se dan cuenta de que el tlatoani ya no ostenta el poder y que de nada les sirve y más bien se convierte en una carga cuando preparaban su huída en lo que se conocerá como la "Noche Triste". ${ }^{17}$

La huída de la "Noche Triste" va a ser una derrota tremenda para el ejército español y sus aliados. ¿Cuáles fueron sus consecuencias? Pérdida de parte de las tropas españolas e indígenas, armamento, cargas de oro, caballos, en fin, que el mismo Cortés considera que fue un desbarajuste. Muere uno de sus capitanes, Juan Velázquez de León, quien estaba a cargo de la retaguardia. Pese a esto, los vencidos continúan su marcha hacia Tlaxcala asediados por los mexicas y antes de llegar se lleva a cabo la batalla de Otumba, en donde el triunfo corresponde a las huestes españolas. Así las cosas, el ejército se va a reponer y Cortés comienza con la construcción de los bergantines en número de 13 y ordena traer los aparejos que se encontraban en los navíos que había encallado en la costa.

El regreso de Cortés para conquistar Tenochtitlan y Tlatelolco va a darse a continuación. Despliega sus tropas de manera tal que controla los accesos por las calzadas que dan a tierra firme y lanza los bergantines al lago, con lo cual se hace del control del mismo. Rompe los acueductos que llevan agua a Tenochtitlan, con lo cual la ciudad queda sin agua potable y las fuerzas de a pie no permiten acceso alguno de bastimentos ni ayuda militar. Comienza un asedio de casi tres meses a las dos ciudades mexicas de Tenochtitlan y Tlatelolco, lo que terminará con el triunfo español y de sus aliados indígenas aquel 13 de agosto de 1521.

Para finalizar con el tema de la conquista militar sólo voy a referir el diálogo que se da entre Cuauhtémoc y Cortés aquel aciago día para el mexica. Cuauhtémoc es hecho prisionero y

17 Matos, Mentiras y verdades. 
llevado ante la presencia del capitán extremeño. Atendiendo a su carácter de tlatoani, "el que habla”, se dirige a Cortés y le dice: "Señor Malinche, ya he hecho lo que soy obligado en defensa de mi cibdad y vasallos, y no puedo más; y pues vengo por fuerza y preso ante tu persona y poder, toma ese puñal que tienes en la cinta y mátame luego con él”. ${ }^{18}$

Muchas veces he comentado cómo lo que quiere decir el tlatoani es otra cosa. Hay una enorme diferencia entre lo que significa "matar" y "sacrificar". Esto último es lo que pide Cuauhtémoc. La diferencia entre uno y otro vocablo es clara: la primera alude a "quitar la vida"; en tanto que sacrificar significa "hacer sacrificio, ofrecer o dar una cosa en reconocimiento de la divinidad". ¿Por qué menciono esto? Porque el destino que se deparaba a los guerreros muertos en combate o hechos prisioneros y ofrendados a los dioses era el de ser sacrificados para que con su corazón alimentaran al Sol y éste continuara día a día su marcha y que, por lo tanto, perdurara la vida del universo. No de otra manera se pueden entender las palabras del capitán mexica, que ha sido vencido y desea cumplir su ciclo como guerrero.

Pero lejos está Cortés de entender esto... y lo perdona.

\section{EL LENGUAJE EN LA CONQUISTA ESPIRITUAL}

Cumplida la misión del aparato militar por lo menos en lo que a la conquista de Tenochtitlan y Tlatelolco se refiere, le corresponde ahora entrar en acción al aparato ideológico que recae en la Iglesia católica. Siempre he comentado que al triunfo militar le va a seguir una batalla más difícil: la de pretender cambiar la manera de pensar de un pueblo. Tarea difícil pero no imposible, la iglesia entra en acción de inmediato y acude a diferentes medios para lograrlo. Así, podríamos hablar de distintos tipos

\footnotetext{
18 Díaz del Castillo, Historia verdadera de la conquista de la Nueva España, I, p. 676.
} 
de lenguaje: el lenguaje a través de la palabra (sermones, cantos, educación, diálogos, etc.); el lenguaje que se transmite por medio de la arquitectura; el uso de las pictografías, imágenes y esculturas; el lenguaje corporal; la confesión o el lenguaje silencioso, y finalmente el lenguaje celestial.

Una de las primeras tareas que los evangelizadores emprenden es la de penetrar en el pensamiento y costumbres indígenas. Para ello ponen en marcha diversas prácticas, como es la de aprender las lenguas locales. Conocer la lengua es prioritario y hay una razón importante para ello: conociéndola podrán acceder directamente al pensamiento indígena y saber de primera mano todo lo relacionado con su cosmovisión, deidades, costumbres, religión, en fin, todo aquello que atañe a la vida diaria y de manera muy especial aquello que tiene que ver con rituales y fiestas a sus dioses. Fray Bernardino de Sahagún es claro al respecto. $\mathrm{Al}$ inicio de sus doce libros advierte el franciscano:

El médico no puede acertadamente aplicar las medicinas al enfermo [sin] que primero conozca de qué humor o de qué causa procede la enfermedad; de manera que el buen médico conviene sea docto en el conocimiento de las medicinas y en el de las enfermedades, para aplicar conveniblemente a cada enfermedad la medicina contraria [y porque] los predicadores y confesores médicos son de las ánimas, para curar las enfermedades espirituales conviene [que] tengan experiencia de las medicinas y de las enfermedades espirituales: el predicador de los vicios de la república, para enderezar contra ellos su doctrina; y el confesor, para saber preguntar lo que conviene y entender lo que dijesen tocante a su oficio, conviene mucho que sepan lo necesario para ejercitar sus oficios; ni conviene se descuiden los ministros de esta conversión con decir que entre esta gente no hay más pecados que borrachera, hurto y carnalidad, porque muchos otros pecados hay entre ellos muy más graves y que tienen gran necesidad de remedio. Los pecados de la idolatría y ritos idolátricos, y supersticiones 
idolátricas y agüeros, y abusiones y ceremonias idolátricas, no son aún perdidos del todo.

Para predicar contra estas cosas, y aun para saber si las hay, menester es de saber cómo las usaban en tiempo de su idolatría, que por falta de no saber esto en nuestra presencia hacen muchas cosas idolátricas sin que lo entendamos. Y dicen algunos, excusándolos, que son boberías o niñerías, por ignorar la raíz de donde salen: que es mera idolatría, y los confesores ni se las preguntan ni piensan que hay tal cosa, ni saben lenguaje para se los preguntar, ni aun la entenderán aunque se lo digan. Pues porque los ministros del Evangelio que sucederán a los que primero vinieron, en la cultura de esta nueva viña del Señor no tengan ocasión de quejarse de los primeros por haber dejado a oscuras las cosas de estos naturales de esta Nueva España, yo, fray Bernardino de Sahagún [...] escribí doce libros de las cosas divinas, o por mejor decir idolátricas, y humanas y naturales de esta Nueva España [...].

Más adelante continúa diciendo el franciscano en relación con el lenguaje:

Es esta obra como una red barredera para sacar a luz todos los vocablos de esta lengua con sus propias y metafóricas significaciones, y todas sus maneras de hablar, y las más de sus antiguallas buenas y malas; es para redimir mil canas, porque con harto menos trabajo de lo que aquí me cuesta, podrán los que quisieren saber en poco tiempo muchas de sus antiguallas y todo el lenguaje de esta gente mexicana. ${ }^{19}$

Queda clara la intención del fraile: por orden de sus superiores se va a entregar a la tarea de dejar constancia de la forma de pensar y actuar de los recién conquistados. Pero si entramos más a fondo en sus palabras, veremos cómo escribe para sus hermanos

19 SAHAgún, Historia general de las cosas de Nueva España, I, pp. 27-29. 
evangelizadores predicadores y confesores con la idea de que no vean con superficialidad lo que ante sus ojos se presenta, sino que deben penetrar en el interior del pensamiento indígena para borrar toda huella de idolatría. Para lo anterior los frailes van a poner en práctica diversos métodos: desde destruir templos y esculturas mexicas hasta dialogar con sabios indígenas y construir amplios atrios con capillas abiertas frente a las iglesias; llevar a cabo danzas de moros y cristianos; usar pictografías como los llamado códices "testerianos", además de imágenes tanto en pintura como en escultura y, cuando el poder humano ya no sea capaz de dar más, entonces se acudirá al apoyo divino por medio de apariciones milagrosas. Veremos ejemplos de cada uno de ellos.

Uno de los primeros encuentros o diálogos entre evangelizadores y sabios indígenas fue aquel que se llevó a efecto en México-Tenochtitlan en 1524. Se reunieron los doce franciscanos, recién llegados, con sacerdotes o sabios mexicas y dialogaron entre sí acerca de sus respectivas religiones. Los diálogos fueron publicados en 1986 por el empeño del doctor Miguel León Portilla. El estudioso nahuatlato tuvo a su cargo la edición facsimilar, la introducción, paleografía, versión del náhuatl y notas de los Coloquios y doctrina cristiana, de donde tomamos los datos que a continuación se expresan. ${ }^{20}$

Un dato de sumo interés nos lo da fray Gerónimo de Mendieta acerca del encuentro entre los sabios. Dice así: “[...] luego como llegaron a México los doce célebres franciscanos, entablaron éstos [por la lengua de Jerónimo de Aguilar y la Malinche] [...] pláticas con los señores y caciques, dándoles cuenta de su venida...". En su mismo libro comenta el fraile: "fray Bernardino de Sahagún, [que] trabajó en esta obra de la conversión y doctrina de los indios más de sesenta años, dejó entre otros escritos estas pláticas" [...]. ${ }^{21}$

20 León Portilla, Coloquios.

21 Mendieta, 1870, en León Portilla, Coloquios, p. 18. 
No voy a comentar las características de los Coloquios pues han sido profusamente estudiados por León Portilla. Pasaré a dar algunos ejemplos de los diálogos que nos ilustrarán sobre la manera de pensar de dos visiones diferentes del mundo. Así, al referirse a los dioses mexicas, los frailes dicen:

Estas cosas dichas, amigos nuestros, todos las abemos visto con nuestros ojos y sabemos que pasan ansí y tenemos entendido que adoráis no tan solamente un Dios, pero mucho cuento y las estatuas de piedra y de madera las tenéis por Dioses. Al uno llamáis Tezcatlipuca, a otro Quezalcoatl, al otro Vicilubuchtli, etc. y a cada uno llamáis dador de la vida y del ser y conservador della; y si ellos son dioses dadores del ser y de la vida, ¿por qué son engañadores y burladores? ¿Por qué os atormentan y fatigan con diversas aflicciones? Esto por esperiencia lo sabéis, que cuando estáis afligidos y angustiados con impaciencia los llamáis de putos y bellacos, engañadores, viejas arrugadas. Demás desto demandavan os vuestra propia sangre y vuestros corazones en ofrenda y sacrificio. Sus imágenes y estatuas son espantables, suzias y negras y hediondas: desta condición son vuestros dioses a quien adoráis y reverenciáis; antes son enemigos matadores y pestilenciales que no dioses. ${ }^{22}$

La incomprensión total queda de manifiesto en esta parte del discurso. Es lógico, hasta cierto punto, que los frailes atacaran de esta manera a los dioses mexicas pues todo aquello era obra del demonio, según su parecer. Hemos escogido una parte en la que los tlamatinime dan respuesta a los franciscanos. Dice así:

Avéisnos dicho que no conocemos a aquel por quien tenemos ser y vida y que es Señor del cielo y de la tierra. Ansí mismo dezís que los que adoramos no son dioses. Esta manera de hablar hácesenos

22 León Portilla, Coloquios, p. 83. 
muy nueva y esnos muy escandalosa; espantámonos de tal decir como éste, porque los padres antepasados que nos engendraron y regieron no nos dixeron tal cosa; más ante ellos nos dexaron esta costumbre que tenemos de adorar nuestros dioses, y ellos los creyeron y adoraron todo el tiempo que vivieron sobre la tierra; ellos nos enseñaron de la manera que los abíamos de honrar; y todas las ceremonias y sacrificios que hazemos ellos nos los enseñaron; dexáronnos dicho que mediante éstos bivimos y somos y que éstos nos merecieron para que fuésemos suyos y los serviésemos en innumerables siglos antes que el sol comenzase a resplandecer ni a aver día; ellos dixeron que estos dioses que adoramos nos dan todas las cosas necesarias a nuestra vida corporal: el mayz, los frisoles, la chía, etc.; a éstos demandamos la pluvia para que se crien las cosas de la tierra". 23

Las palabras de los sabios nahuas son de extrema prudencia. Difícil debió de ser la situación en que se encontraban ya que, al fin y al cabo, habían sido vencidos. ¡Ay de los vencidos! Reza la frase. Estos diálogos no deben de haber llegado a más: unos se creían portadores de la verdad absoluta en tanto que los otros veían a sus templos y dioses destruidos.

Pasemos ahora a otro medio empleado por los conquistadores. Se trata de la construcción de grandes atrios o espacios abiertos frente a las iglesias. Esto obedeció, durante el siglo Xvi, a la observación que hicieron los frailes de las ceremonias que practicaban los indígenas en las grandes plazas prehispánicas. En aquella época los templos se encontraban en la parte superior de grandes basamentos y a ellos sólo accedían los sacerdotes y los iniciados. El pueblo participaba desde las plazas de gran tamaño que servían para que se concentraran en determinadas ceremonias. Esta práctica prevaleció desde épocas muy tempranas y se han encontrado en Teotihuacan,

${ }^{23}$ LeÓn Portilla, Coloquios, p. 88. 
Monte Albán, Tenochtitlan, Tlatelolco y muchas más. Lo importante de esto es que los indígenas no estaban acostumbrados a entrar al templo, por lo que es de imaginar que en un principio hubiera resistencia en hacerlo así. Por lo tanto, los atrios jugaban el papel de estas plazas y más aún, con el fin de que los indígenas pudieran observar la misa y otras ceremonias, se construyeron las llamadas "capillas abiertas" como parte de la fachada de la iglesia y con ello se lograba dicha participación. De esta manera se combinaban la palabra y la arquitectura para lograr sus propósitos.

Las danzas de moros y cristianos y otras representaciones similares tuvieron amplia presencia en la España de la reconquista. En diversas regiones del país se suelen realizar hoy día estas danzas cuya finalidad fue realzar el triunfo del cristianismo sobre la morería. Con su raigambre peninsular, fueron traídas a la Nueva España como un medio, entre otros, de ayudar en la catequización de los conquistados. Las diversas danzas y sus variantes -danzas de la conquista, La toma de Jerusalem, Los doce pares de Francia (basada en la Chanson de Roland), o la representación de pasajes bíblicos y los autos sacramentales, etc.- proliferaron de manera espectacular en el Nuevo Mundo y en México las vemos representadas en la actualidad en muchas poblaciones por los habitantes de la localidad. Estas danzas tuvieron buena acogida, ya que en el mundo prehispánico se acostumbraba que toda celebración a sus dioses estuviera acompañada de danzas, música y cantos. Haciendo un alarde de simplificación, comento que en términos generales estas representaciones muestran dos bandos, los moros, por un lado, y los cristianos, por el otro, y en un principio eran representaciones masivas, pero también en algunos casos los dos bandos antagónicos se componían de 12 personajes por cada lado que se ataviaban para la ocasión y portaban máscaras de los individuos a los que representaban. Así vemos a Carlomagno, Floripes, Rolando y otros según 
la versión en escena. Actualmente aún se hacen en espacios abiertos y la mayoría se caracterizan por conjugar diálogos que se intercambian entre los dos grupos y se acude al lenguaje corporal con danzas, combates, embajadas, todo ello acompañado de música.

A raíz de la conquista sabemos de la puesta en escena de " $\mathrm{La}$ conquista de Rodas" en la ciudad de México en 1538 y un año más tarde de la "Destrucción de Jerusalem" en Tlaxcala el día de Corpus Christi. Un relato de ello lo ha dejado fray Toribio de Benavente, "Motolinía", quien señala cómo, en el caso de esta última, por un lado estaban las tropas españolas formadas por grupos de Castilla y León, Toledo, Aragón, Galicia, Granada, Vizcaya y Navarra, formando la retaguardia gentes de Alemania, Roma e italianos, todos bajo el mando de don Antonio Pimentel, conde de Benavente. Aliados de todos éstos eran los tlaxcaltecas, y mexicanos, huastecos, cempoaltecas, mixtecos, colhuaques "y unas capitanías que se decían del Perú e islas de Santo Domingo y Cuba. En la retaguardia iban los tarascos y los cuauhtemaltecas". ${ }^{24}$ Semejante ejército estaba al mando general del primer virrey de México, don Antonio de Mendoza. Lo curioso del caso es que el bando enemigo lo formaban los infieles, quienes tenían como capitanes a Hernán Cortés y a Pedro de Alvarado. ${ }^{25}$ Tan extendida estuvo en América esta práctica que Barbara Bode reporta alrededor de 30 danzas en Guatemala referentes a la conquista de Guatemala y por mi parte encontré una "Danza de los Montezuma" que aún se baila en Panamá y otra con el título "La historia de Montizuma, indio mejicano, y Hernán Cortés, español”, que se baila en El Salvador. Don Pedro Henríquez Ureña narra cómo vio estas danzas en México y añade: "En la Sierra del Perú se ve todavía entre los indios la danza coral de la prisión y muerte de Atahualpa. Hasta en las

${ }^{24}$ Motolinía, 1941, pp. 96-97.

25 Matos, "La Danza de los Montezumas". 
Antillas, en la ciudad de Santo Domingo, sobrevivía hasta 1900 una danza tradicional sobre la conquista de México, la Danza de los Montezumas". ${ }^{26}$

Un mínimo ejemplo de uno de los diálogos lo tomamos de la que se ejecuta en Panamá. Montezuma ha sido vencido y Cortés pretende llevarlo a España:

La orden que me dio

Carlos V fue,

que te llevara a España

porque te quería ver.

Coro español:

Victoria, victoria,

soldados de España;

que ya se dio este Rey

de riqueza y fama.

Montezuma y Cortés:

A los que presencien

y escuchen esta historia,

que nos vayamos juntos

a la eterna gloria.

Coro: (indios y españoles):

Ángeles del cielo

las alas tended,

que pasa María

y Jesús también.

Otra idea que pusieron en práctica los frailes fue aquella de preparar catecismos, oraciones y pasajes bíblicos en grandes lienzos o en pequeñas cartillas a manera de códices que se conocen como "testerianos", pues uno de quienes los llevaron a cabo

${ }^{26}$ Henríquez Ureña en Matos, “La Danza de los Montezumas”, p. 712. 
fue fray Jacobo de Testera. ${ }^{27}$ Del uso de los lienzos nos dice fray Gerónimo de Mendieta:

Algunos [frailes] usaron un modo de predicar muy provechoso para los indios por ser conforme al uso que ellos tenían de tratar todas sus cosas por pintura. Y era de esta manera. Hacían pintar en un lienzo los artículos de la fe, y en otro los diez mandamientos de Dios, y en otro los siete sacramentos, y lo demás que querían de la doctrina cristiana. ${ }^{28}$

A esto hay que agregar imágenes diversas de Cristo, la Virgen, santos, en fin, que fue una proliferación escultórica y pictórica que llevaba como fin ayudar en la conversión de los feligreses.

He hablado del "lenguaje silencioso". Me refiero con esto al sacramento de la confesión. Ya vimos cómo Sahagún pone especial énfasis en dicha práctica, que en realidad es un diálogo exclusivo entre dos personas, el confesor y el confesante, y que no debe trascender más allá. Hay que advertir que era un medio importante para conocer en lo individual determinados aspectos personales y es evidente la relevancia que tiene para "saber preguntar lo que conviene”, como dijera el franciscano.

En 1531 ocurrió un acontecimiento que mucho significó para evangelizadores y evangelizados. Se trata de la supuesta aparición de la Virgen de Guadalupe al indio Juan Diego. Cabe aquí señalar que el culto a la Virgen de Guadalupe se dio en España desde el siglo XIv, especialmente en Extremadura, de donde provenían buen número de los conquistadores, incluido Cortés. Esta Virgen, cuyo nombre parece provenir del árabe y el latín (Guada-río; lupus-lobo), obedece al río y población del mismo nombre en la península Ibérica. El culto a la guadalupana de allá

27 Boone, "El discurso en imágenes”; Batalla, "Problemática sobre la datación de los catecismos".

${ }_{28}$ Mendieta, Historia eclesiástica indiana, p. 249. 
proviene del triunfo en la batalla del Salado en contra de los moros y el papel que tuvo la imagen en la conversión. Se le representa con la piel morena, casi negra, para causar un impacto mayor entre los moros. Se trata, pues, de una Virgen probada en cosas de conquista, y de España pasa a México, en donde se le representa de color moreno como una joven india. El autor del relato (Nican mopohua) en que se dan a conocer las apariciones es Antonio Valeriano, alumno de la escuela de Tlatelolco y discípulo de Sahagún. En esta autoría concuerdan Miguel León Portilla y Edmundo O'Gorman, y se piensa que fue escrito alrededor de 1556. Sin embargo, hubo oposición al culto en el Tepeyac pues se pensaba que podría llegar a equipararse al culto a Dios, según lo afirmó en aquel mismo año fray Francisco de Bustamante, provincial de los franciscanos en México. El arzobispo de México, fray Alonso de Montúfar, tomó sus providencias y León Portilla adelanta la idea de que aquel revuelo pudo motivar que el mismo arzobispo encargara a Valeriano el escrito de referencia.

Independientemente de todo lo anterior, lo interesante reside en el patrón que se establece para ciertas apariciones marianas. Tanto en Europa como en América siguen la siguiente pauta:

1.- La aparición escoge a una persona humilde, sencilla, que será el interlocutor con la divinidad.

2.- La persona escogida en enviada ante el representante eclesiástico para decirle que ha ocurrido la aparición.

3.- El mensaje de la persona sencilla es puesto en duda por el eclesiástico.

4.- Es necesario que se dé una prueba de la aparición por medio de un portento milagroso.

5.- Logrado lo anterior, en el lugar de los acontecimientos se construye una iglesia para que los fieles vayan a orar y pedir milagros. ${ }^{29}$

${ }_{29}$ Matos, Nonagenario cuidam dicata. Homenaje a Miguel León Portilla. 
Todo lo anterior nos da un panorama acerca de la manera en que los frailes llevaron a cabo su misión evangelizadora. Cuando fue necesario también se acudió a escarmentar a los feligreses con medidas más severas que llegaron, incluso, a la tortura. Recordemos el auto de Maní, en Yucatán, a manos de fray Diego de Landa. Pero no debemos extendernos más pues pienso que con lo dicho tenemos una idea clara de los medios empleados en los que el lenguaje en sus diferentes formas predominó para llevar a cabo la acción evangelizadora.

\section{REFERENCIAS}

Alvarado Tezozómoc, Hernando, Crónica mexicáyotl, México, Universidad Nacional Autónoma de México, 1975.

Batalla Rosado, Juan José, "Problemática sobre la datación de los catecismos en pictogramas o códices testerianos", en A. ОсноA y E. Matos Moctezuma (eds.), Del saber ha hecho su razón de ser... Homenaje a Alfredo López Austin, México, Secretaría de Cultura, Instituto Nacional de Antropología e Historia, Universidad Nacional Autónoma de México, 2017, t. II, pp. 45-65.

Boone, Elizabeth, "El discurso en imágenes”, en Homenaje a Alfredo López Austin, México, Secretaría de Cultura, Instituto Nacional de Antropología e Historia, Universidad Nacional Autónoma de México, 2017, t. II, pp. 27-43.

Chimalpahin Cuautehuanitzin, Francisco de San Antón, Relaciones originales de Chalco Amaquemecan, México, Fondo de Cultura Económica, 1965.

Códice Ramírez, en Hernando Alvarado Tezozómoc, Crónica mexicana, México, Porrúa, 1980.

CoRTés, Hernán, Cartas de relación de la conquista de América, México, s/f., t. I.

Díaz del Castillo, Bernal, Historia verdadera de la conquista de la Nueva España, México, Academia Mexicana de la Lengua, 2014, 2 tomos.

León Portilla, Miguel, Coloquios y doctrina cristiana, México, Universidad Nacional Autónoma de México, Fundación de Investigaciones Sociales, 1986. 
León Portilla, Miguel, Tonantzin Guadalupe. Pensamiento nábuatl y mensaje cristiano en el "Nican mopohua", México, El Colegio Nacional, Fondo de Cultura Económica, 2000. Una reseña del libro salió publicada en Eduardo Matos Moctezuma, Nonagenario cuidam dicata. Homenaje a Miguel León Portilla, México, El Colegio Nacional, Opúsculos, 2016.

Matos Moctezuma, Eduardo, "La Danza de los Montezumas”, en Anales del INAH, 47, t. XVIII (1965), Sexta Época (1939-1966). También en Estudios de Cultura Popular, México, INI, 1981.

Matos Moctezuma, Eduardo, "La Conquista de México", en Arqueología Mexicana, núm. especial 93 (2020).

Matos Moctezuma, Eduardo, Mentiras y verdades en la arqueología mexicana, México, Secretaría de Cultura, Instituto Nacional de Antropología e Historia, México, Raíces, 2018.

Mendieta, Gerónimo, Historia eclesiástica indiana, México, Porrúa, 1971.

SAHAGÚN, Bernardino, Historia general de las cosas de Nueva España, estudio de Ángel María Garibay, México, Porrúa, 1956. 